\title{
Bentonites in Southern Spain. Characterization and Applications
}

\author{
Jorge Luis Costafreda *(1) and Domingo Alfonso Martín
}

check for

updates

Citation: Costafreda, J.L.; Martín, D.A. Bentonites in Southern Spain. Characterization and Applications. Crystals 2021, 11, 706. https:// doi.org/10.3390/cryst11060706

Academic Editor: Zhaohui Li

Received: 23 May 2021

Accepted: 17 June 2021

Published: 20 June 2021

Publisher's Note: MDPI stays neutral with regard to jurisdictional claims in published maps and institutional affiliations.

Copyright: (c) 2021 by the authors. Licensee MDPI, Basel, Switzerland. This article is an open access article distributed under the terms and conditions of the Creative Commons Attribution (CC BY) license (https:// creativecommons.org/licenses/by/ $4.0 /)$.
Escuela Técnica Superior de Ingenieros de Minas y Energía, Universidad Politécnica de Madrid, C/Ríos Rosas, 21, 28003 Madrid, Spain; domingoalfonso.martin@upm.es

* Correspondence: jorgeluis.costafreda@upm.es

\begin{abstract}
The objective of this work was to investigate and demonstrate the pozzolanic properties of the bentonites found at the San José-Los Escullos deposit, located in the southeast of the Iberian Peninsula, to be used in the manufacturing of more durable and environmentally compatible pozzolanic cements, mortars and concretes. These bentonites are mainly composed of smectites, with montmorillonite as the main clay mineral. They were formed by the hydrothermal alteration of tuffs, volcanic glasses, dacites, rhyolites and andesites. For this research, samples were taken from outcrops on the south, north and west side of the San José-Los Escullos deposit, and in the Los Trancos deposit located $19.3 \mathrm{~km}$ to the northeast. All samples consisted of bentonites, except for a zeolite sample taken from the northern flank of the San José-Los Escullos deposit, which was used to contrast and compare the behaviour of bentonite in some of the analyses that were done. An investigation of the mineralogical, petrological, chemical and thermogravimetric characteristics of the samples was carried out using various methods, such as XRD, OA (Oriented aggregates), TGA, XRF, SEM and thin section petrography (TSP). In addition, a chemical analysis of pozzolanicity (CAP) was done at 8 and 15 days to determine the pozzolanic capacity of the samples. XRD, XRF, SEM and TSP studies showed that these bentonites have a complex mineralogical constitution, composed mainly of smectites of the montmorillonite variety, as well as halloysite, illite, vermiculite, biotite, muscovite, kaolinite, chlorite, mordenite, feldspar, pyroxene, amphibole, calcite, volcanic glass and quartz. Thermogravimetric analysis (TGA) established the thermal stability of the bentonites studied at above $800{ }^{\circ} \mathrm{C}$. Chemical analysis of pozzolanicity (CAP) confirmed the pozzolanic character of the bentonites, exhibited in their reactive behaviour with $\mathrm{Ca}(\mathrm{OH})_{2}$. The pozzolanic reactivity increased significantly from 8 to 15 days. These results show that the materials studied can be used as quality pozzolans for the manufacture of pozzolanic cements, mortars and concretes.
\end{abstract}

Keywords: bentonite; mordenite; smectite; pozzolanicity test; cement; concrete

\section{Introduction}

This research focused on the characterisation and uses of bentonites from the San José-Los Escullos deposit as pozzolans for the manufacture of pozzolanic cements, mortars and concretes. There are no previous reports on the use of bentonites from this deposit for these specific purposes, so the results presented here are considered new. However, the use of bentonites is broad and diverse, as described below.

Bentonites have been used in many fields for several decades. Due to their chemical, mineral and technical properties, the bentonites from Sardinia (Italy) were used to prepare bentonite pastes to be used in pelotherapy [1], thus substituting traditional peloids. Nowadays, the use of bentonites is so diverse that they are used in many sectors of the economy, science and technology [2]. There is a current trend to thermically activate the bentonites to facilitate the production of geo-polymer binding agents [3]. The heated bentonites quickly acquire pozzolanic activity, as has been proven by Habert et al. [4]. They proved that by heating the bentonites between 20 and $900{ }^{\circ} \mathrm{C}$ it is possible to raise the mechanical resistance 
of the mortar up to $60 \mathrm{MPa}$ in 28 days. Kaci et al. [5] proved the influence of bentonite on the rheologic behaviour of the mortar, especially regarding the fluency and thixotropy, and arrived at the conclusion that bentonite improves the resistance of the mortar. To mitigate the effects of copper mining, Bertagnolli et al. [6] used thermically activated bentonitic clay in the porous beds to absorb the copper. Slamova et al. [7] proved the role of clay in animal food and formulated procedures of application to avoid gastrointestinal disorders in these animals; they highlighted that the clay minerals with a fine granulometry and a high capacity for absorption are the most effective for veterinarian use. Pelayo [8] proved the behaviour of bentonite as an efficient insulator in storing radioactive residue in his research on bentonites from the Morrón de Mateo mineral deposit, in the south east of the Iberian Peninsula. Hassan and Abdel [9] made a mixture out of bentonite-zeolite with a 1:10 ratio to improve the productivity of the crops in sandy and arid soils. Recent research shows great appreciation for products that are absorbent, catalysts and biomaterials [10]. Park et al. [11] list a series of uses for the clay bentonites in drilling mud, whitening products, stabilising emulsions, in the smelting industry, drying products, catalysts, adhesive seals, cosmetics and pharmaceutical products. Panday and Ramontja [12] list in detail the most recent progress in the use of bentonite and its compounds to eliminate contaminating synthetic dyes in water. Luqman and Enobong [13] used bentonite as a base to prepare sol-gel to obtain bioactive glass, significantly lowering the costs generated using old precursors to alkoxysilane. Aravindhraj and Sapna [14] were able to raise the resistance to compression and flection of concrete, mortars and cements, substituting the cement for bentonite in $15 \%$, which also made it exceptionally durable against the effects of sulphate and chlorides. In the process of de-fluoridisation of the waters, Masindi [15] patented a simple, new and innovative method in the synthesis of cryptocrystalline magnesite from bentonites, which notably surpasses the absorption capacity of fluoride in conventional products. Masindi [15] also proved that bentonite that is ground up to the correct size can be used efficiently in the management, neutralisation and remediation of acid waters from mines. The effectiveness of this fact is because the thermic activation of the pores and micropores increases, thus facilitating an ionic exchange between the copper and the interlaminar cations. Kim et al. [16] have recently proposed a numerical model based on the relationship between density and thermal-hydraulic properties of compacted bentonite for sealing high-activity waste tanks. Masood et al. [17] made compound concretes with low calcium and arid bentonite compounds that came from recycled concrete. The bentonite substituted the cement in 5\%,10\%,15\% and 20\%. The concretes were significantly efficient regarding durability and mechanical resistances; on the other hand, it was highlighted as a good response to the environmental problem. Wu et al. [18] made a mixed compound based on reactive $\mathrm{MgO}$, blast furnace grinded granulated slag, bentonite and clay sand to improve soils. Bentonites are currently being used successfully to make high activity radioactive waste inert, in the form of a paste fabricated from grains, particulates and bentonite dust [19].

\section{Geological Settings}

The study area is in the province of Almería (Spain) between the municipalities of San José de Nijar and Los Escullos (Figure 1). The research took place inside of the Los Frailes caldera, a volcanic structure that was formed 14.4 million years ago in the southeast of the Iberian Peninsula, before the other surrounding calderas were formed, as Rodalquilar and La Lomilla. The Los Frailes caldera is a circular megastructure slightly larger than $5 \mathrm{~km}$ in diameter $[20,21]$.

The geology is made up of rocks that were formed during the volcanic processes of the Neogene and are mainly andesites and dacites from the Unidad Frailes 1 (UFR-1), dacites and rhyolites from the Rodalquilar Complex, as well as basaltic andesites and post-caldera pyroxene andesites from the Unidad Frailes 2 (UFR-2) [21-23]. The rocks of a half acid composition, as dacites and rhyolites, make dykes and domes, whereas the most basic lithologies like the andesites, form great lava flows and pyroclastic breccia (Figure 2) [24]. 


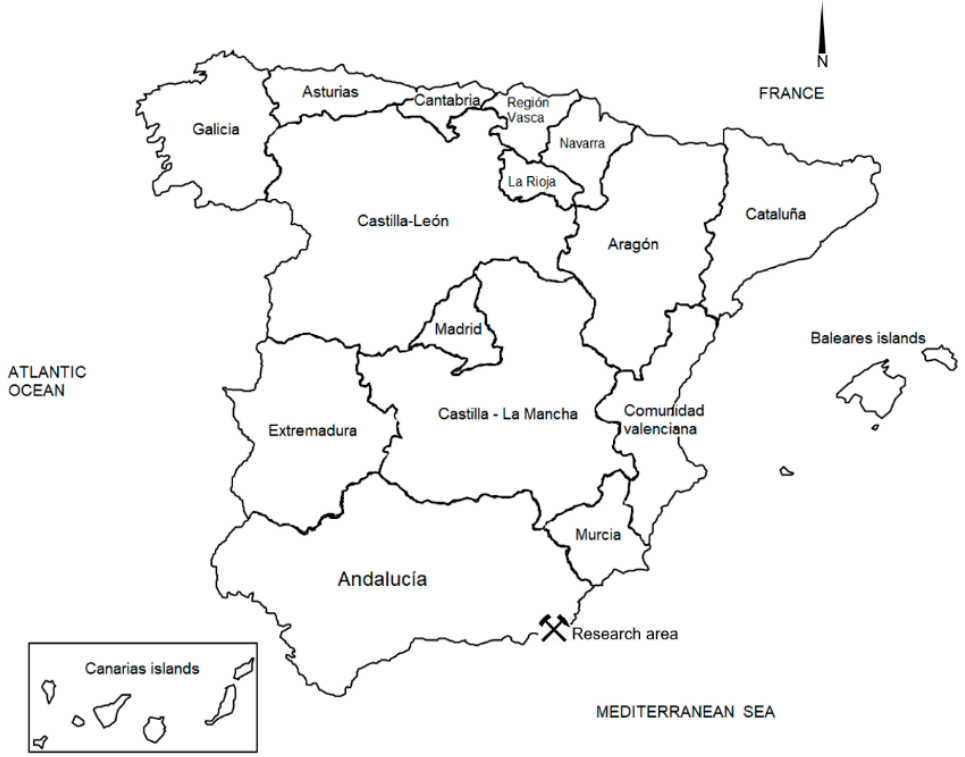

Figure 1. Geographic location map.

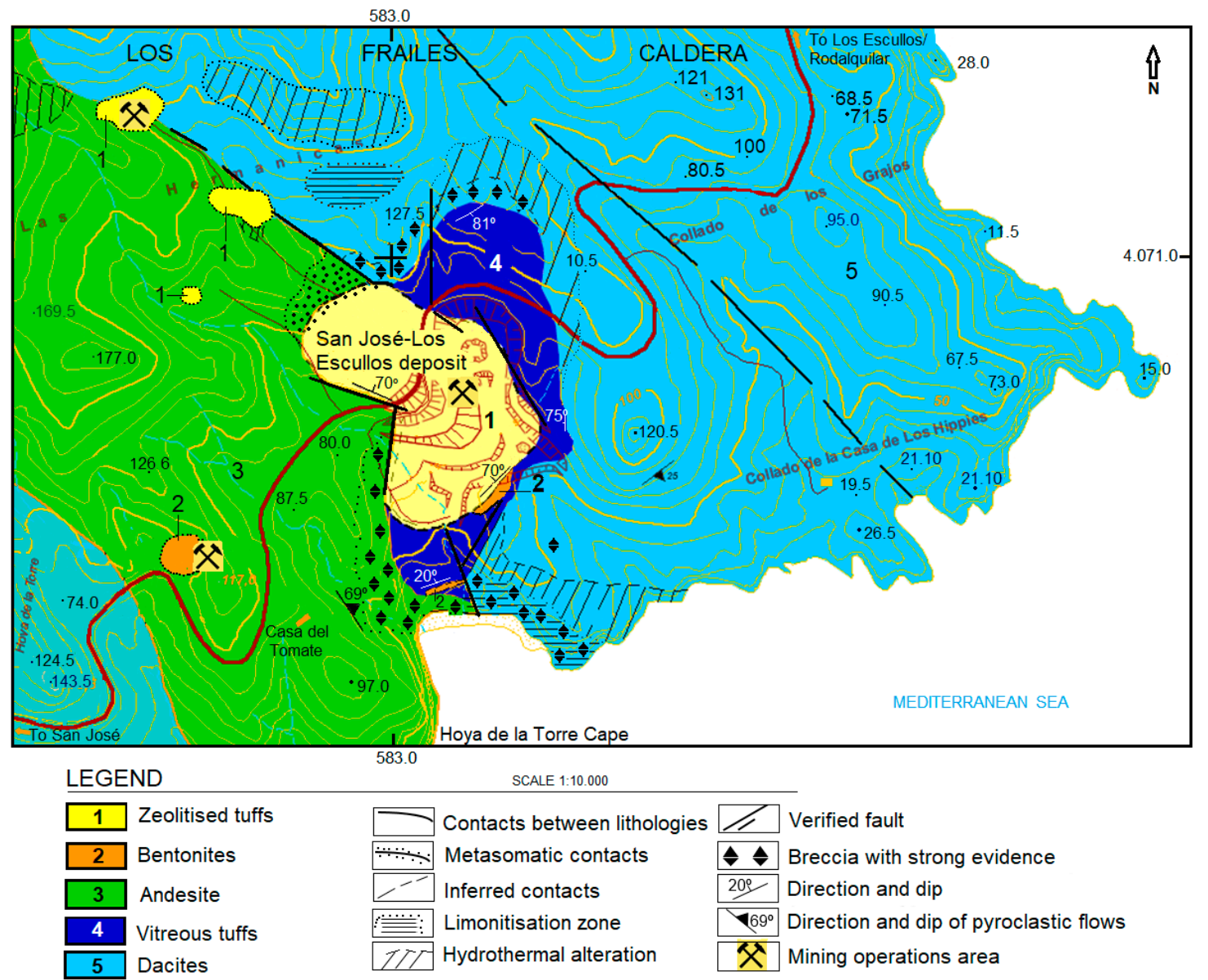

Figure 2. Geological map of the research area. Modified from Costafreda [24].

Generally, bentonites are stratified, banded and changed by spheroidal weathering. They are highly friable and mylonitised. Their colour is a characteristic beige (Figure 3). Occasionally they include dacite pyroclastic and tuff materials. The outcrops are cut by vertical and subvertical diaclases with a dip between $70^{\circ}$ and $80^{\circ}$ towards the west [24]. 


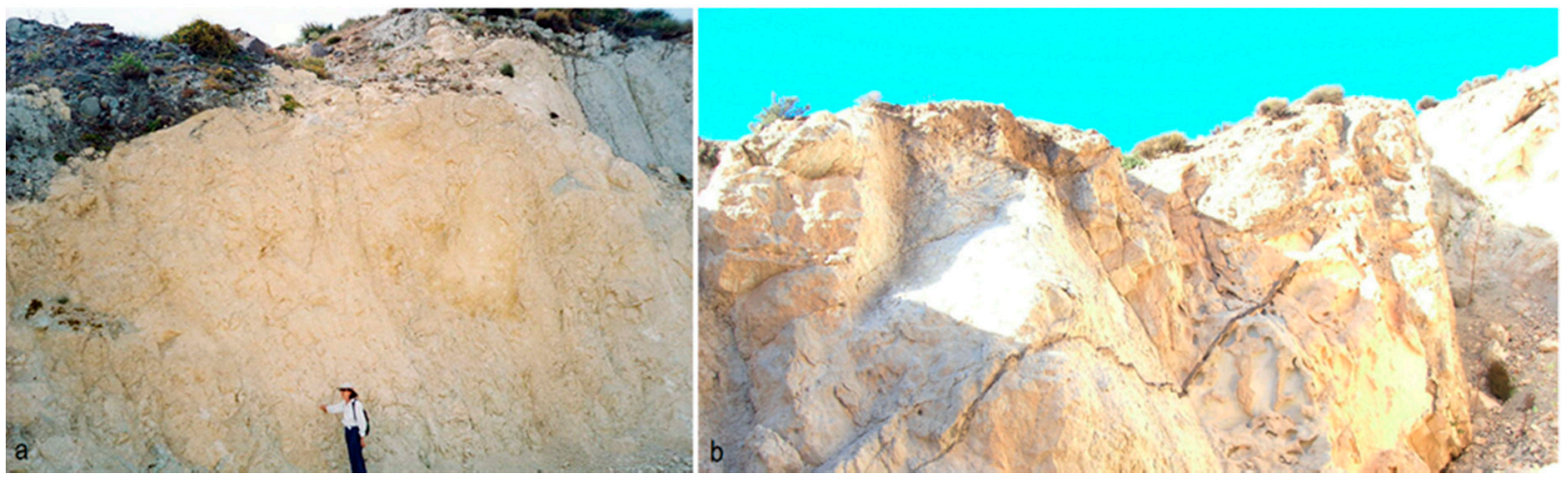

Figure 3. View of two bentonite outcrops in the south (a) and west (b) of the research area.

The bentonite deposits are well represented in the study area. In UFR-1, the bentonite has been formed by fine lapilli and bentonised ash; these are in Cerro de la Palma and in Barranco de Cala Higuera. In Rodalquilar, the dacite tuffs are bentonised and form industrial deposits in the Rambla del Plomo [8,25-27].

The most representative outcrops of the area of research are in a small area of the southern flank of the San José-Los Escullos deposit, as well as in the western part of the same area (Figure 3a,b).

\section{Materials and Methods}

\subsection{Materials}

The research area is in the east of San José and to the west of Los Escullos. In this place the bentonites form a representative outcrop on the southern side of the San José-Los Escullos deposit. Five samples of bentonite were taken directly from the outcrops for this research and were designated with the codes B-01 through B-05 (Figure 4a).

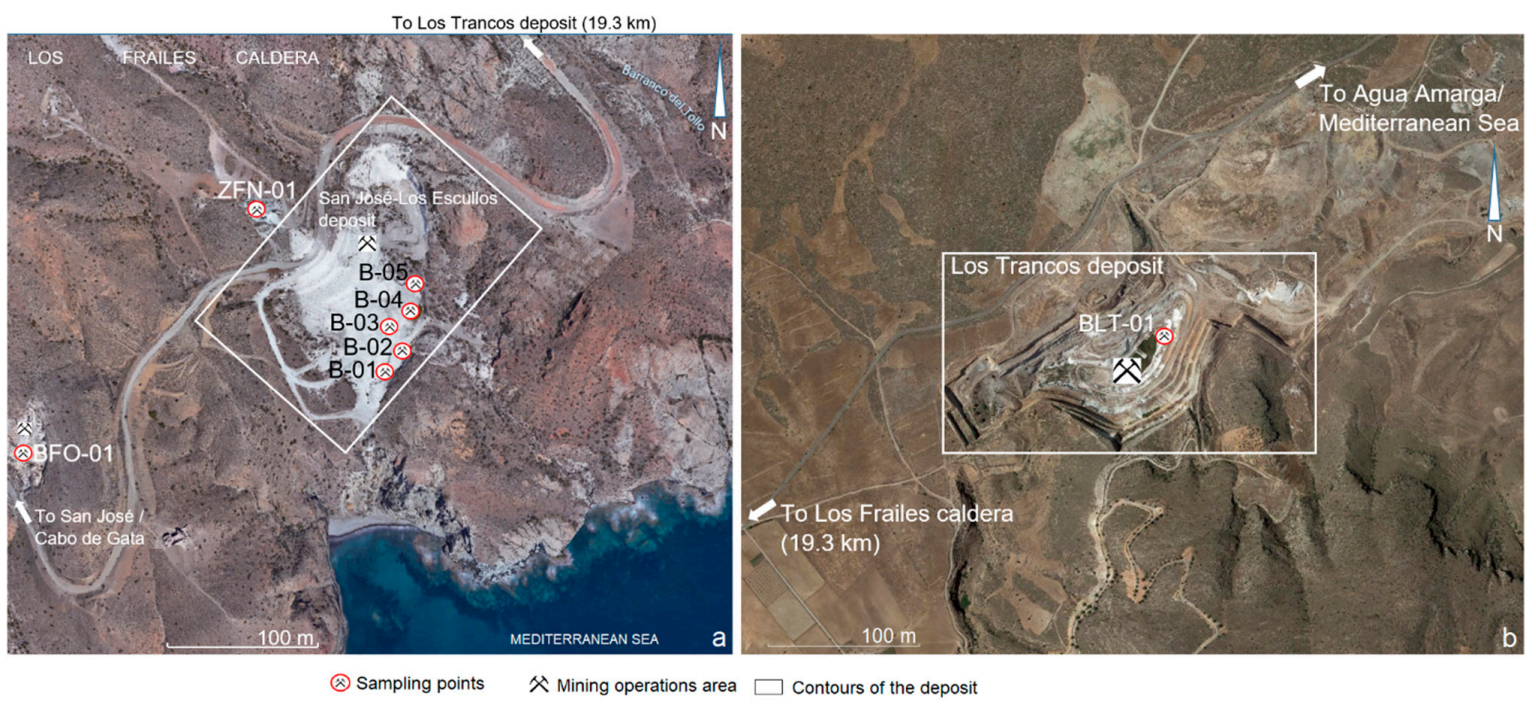

Figure 4. Location of sampling points: (a) samples taken in the San José-Los Escullos deposit; (b) sample taken in the Los Trancos deposit [28].

Another three samples were taken outside of the deposit limits to make comparative studies. These are: BFO-01, ZFN-01 and BLT-01 (Figure 4a,b).

The dacite has a massive, uniform, vesicular and brecciated structure. It has a mediumgrained, porphyritic, phaneritic texture. Its colour varies from dark grey to green. It is generally altered by limonite, sericite and chlorite. The dacite is composed of phenocrystals of amphibole, pyroxene and plagioclase, as well as sericite, glass, iron oxide and opaques. 
Andesite is dark grey to green in colour, with a brecciated and prismatic-columnar structure. It is composed of plagioclase, pyroxene, glass, sericite and opaques. Its texture is porphyritic. It is strongly altered to zeolite near the fault systems. Plagioclases are sericitised, while pyroxenes are chloritised. The pyroxenes and plagioclases are replaced by zeolites.

Bentonite varies in colour from light grey, green, beige to yellow. It has a stratified structure. The texture is cinereous and devitrified. It is formed mainly by smectite, and montmorillonite the main mineral, as well as altered glass, relict crystals and fragments of rocks altered to smectite, zeolite and serpentine. The bentonite is weathered and fractured in the outcrops.

Zeolite is white, light grey and green in colour. Its structure is massive and compact, becoming brecciated. It is mainly composed of the mordenite, accompanied by smectite, plagioclase, potassium feldspar, quartz, hematite, amorphous materials and traces of gypsum. They are altered in outcrops, forming shallow, residual and porous clay layers. Outcrops are marked by abundant diaclases and fissures. Mordenite appears as elongated, fibrous and tabular crystals associated with montmorillonite, halloysite, kaolinite and micas.

\subsection{Methods}

\subsubsection{Petrography Characterisation by Thin Section (PTS)}

Petrographic analysis was carried out to describe the properties of the samples analysed: mineral type, texture, colour, grain size, alterations (zeolitisation and bentonisation) as well as petrogenesis. The equipment used was a Leica DM600M microscope (Leica, Weztlar, Germany). It has an adapted system of 13 filters (DTA-RPFMAX) for visible and infrared light at 13 wavelengths, from $350 \mathrm{~nm}$ to $1000 \mathrm{~nm}$, in $50 \mathrm{~nm}$ intervals. It has a LAS control and a Märzhäuser motorised plate. The image analysis software used was APHELION.

\subsubsection{X-ray Diffraction (XRD)}

In the sample analyses the Phillips diffractometer 1710 BASED (Amsterdam, Netherlands) was used with the following characteristics: tube anode of $\mathrm{Cu}$, generator tenson (45 Kv), generator current $30 \mathrm{~mA}$, wavelength Alpha 1 [̊] 1.54060, wavelength Alpha 2 [A] 1.54439, intensity ratio (alpha1/alpha2) 0.500, scan range of software 2 theta $\left(4-60^{\circ}\right)$, monochromator, and PC-APD diffraction software.

\subsubsection{Oriented Aggregates (OA)}

This method was used to determine the clay minerals associated with more crystalline species, as feldspars, quartz and zeolites, present in the researched samples. Some types of clay, such as smectites, chlorites and vermiculites have a $d=14 \AA$. The test procedure consisted of taking $500 \mathrm{mg}$ of each bentonite sample previously crushed, ground and sieved to $2 \mu \mathrm{m}$. Next, the samples were placed in test tubes and mixed with 4-5 drops of sodium hexametaphosphate. They were then allowed to settle. A part of the saturated clay suspension was placed in a glass sample holder for $24 \mathrm{~h}$ at room temperature. After evaporation of the water, a thin layer of clay remained on the sample holder, which was treated with ethylene glycol and heated in an oven at $70-80^{\circ} \mathrm{C}$ for $24 \mathrm{~h}$. During this time, the vapours acted directly on the sample. The samples were then analysed by XRD and the corresponding patterns were obtained.

\subsubsection{Thermogravimetric Analysis (TGA)}

This method consisted in heating the samples and a pattern in a controlled manner. During this process, the temperature difference $(\Delta T)$ was measured based on time. The thermogravimetric analysis (TGA) measured the variation and behaviour of the mass of the samples under the influence of temperature in a controlled atmosphere. This variation manifested in mass loss. The recording and monitoring of the changes gave information 
regarding the decomposition of the sample or of its reaction to other components. This test used Universal equipment V4.1DTA Instruments/2960 SDT V3.OF. A total of $13.1971 \mathrm{~g}$ was analysed for each sample using the $10 \mathrm{C}-1100 \mathrm{~N} 2, \mathrm{~N} 210 \mathrm{~mL} / \mathrm{min}$ method, and the TGA curves were obtained.

It was important to apply this method to the samples because it was important to know the sorbed phases (adsorbed, absorbed and constituent water), porosity, reactions that occur with increasing temperature, weight loss, variations in cation exchange capacity (CEC), increase in active surface area, thermal stability and pozzolanic capacity. These properties are decisive in the manufacture of pozzolanic cements mixed with natural and activated bentonites, which is highly important for the preservation of the environment and the durability of sustainable building materials.

\subsubsection{X-ray Fluorescence (XRF)}

This research used a Philips PW 1404 (Amsterdam, Netherlands) with a collimator, with a radiation intensity between 10 and $100 \mathrm{kV}$, and monochrome was used to isolate the radiation. The preparation of the samples consisted of a previous grinding to 200 mesh. Next, $8 \mathrm{~g}$ of dust with a $1.5 \mathrm{~mL}$ of elbaite were mixed in to make a $5 \mathrm{~cm}$ in diameter paste to be analysed by XRF.

\subsubsection{Scanning Electron Microscopy (SEM)}

The following equipment was used to prepare and analyse the samples: Hitachi S-570 Scanning Electron Microscope (Tokyo, Japan) with a Kevex 1728 analyser, the BIORAD Polaron Division Carbon Evaporation Power Supply and the Polaron SEM Coating System. The Winshell and Printerface software were also used. All the samples were reduced to between 0.2 and $0.5 \mathrm{~cm}$; and were then covered by a layer of graphite and placed in the sample carrier for their analysis.

\subsubsection{Chemical Pozzolanicity Analysis (CPA)}

Pozzolanicity is the property of rocks and minerals to actively react with calcium hydroxide at 40 degrees, once crushed, ground up and micronised to around $63 \mu \mathrm{m}$. Under these conditions they can acquire cementitious properties and develop mechanical strength over time [29]. The aim of this work is to determine the pozzolanic behaviour of the analysed bentonites and to establish their uses in the manufacture of cements, mortars and concretes with excellent durability and mechanical strength.

Pozzolanicity was determined by comparing the amount of calcium hydroxide that exists in a watery dissolution which contains hydrated cement and pozzolan, with enough calcium hydroxide necessary to obtain a saturated dissolution with the same alkalinity as the other sample. The chemical trial for pozzolanicity was done following standard UNE-EN 196-5:2011 [29] to 8 to 15 days. An amount of $100 \mathrm{~mL}$ of distilled water was heated to $40^{\circ} \mathrm{C}$, for $60 \mathrm{~s}$. Twenty grams of sample (bentonite) and cement made up of 75:25 ratio was added. After a week, the solution was filtered. The concentration of the hydroxyl ions $\left[\mathrm{OH}^{-}\right]$was calculated with the following equation:

$$
\left[\mathrm{OH}^{-}\right]=\frac{1000 \times 0.1 \times \mathrm{V}_{3} \times \mathrm{f}_{2}}{50}=2 \times \mathrm{V}_{3} \times \mathrm{f}_{2}
$$

where:

- $\left[\mathrm{OH}^{-}\right]$: is the concentration in hydroxyl ions $(\mathrm{mmol} / \mathrm{L})$.

- $\mathrm{V}_{3}$ : is the volume of the hydrochloric acid solution $(0.1 \mathrm{~mol} / \mathrm{L})$.

- $\mathrm{f}_{2}$ : is the factor of the hydrochloric acid solution $(0.1 \mathrm{~mol} / \mathrm{L})$.

The concentration of calcium oxide $(\mathrm{CaO})$ was calculated using the following equation:

$$
[\mathrm{CaO}]=\frac{1000 \times 0.025 \times \mathrm{V}_{4} \times \mathrm{f}_{1}}{50}=2 \times \mathrm{V}_{4} \times \mathrm{f}_{1}
$$


where:

- $\quad[\mathrm{CaO}]$ : is the concentration in calcium oxide (mmol/L).

- $\mathrm{V}_{4}$ : is the volume of EDTA solution used in the titration.

- $\mathrm{f}_{1}$ : is the factor of the EDTA solution.

The pozzolanicity test is positive when the hydroxide concentration of calcium in dissolution is lower than the saturation concentration [29]. The results are seen in the graph, where all samples below the solubility isotherm curve are considered as pozzolans.

\section{Results and Discussion}

\subsection{Petrographic Study by Thin Section}

The analysed bentonites have a texture that is porphydic, relict, hemivitreous, crystallolithoclastic, pyroclastic and oriented. The predominant minerals are clays (montmorillonitetype smectite), mordenite, plagioclase, biotite, muscovite, hematite, apart from the glass. Subordinately there is quartz, kaolinite and polygenic lithic fragments of a small diameter. Figure $5 \mathrm{a}, \mathrm{b}(\mathrm{N} / \mathrm{/})$ represents a process of strong pyroxene and plagioclase alterations being substituted partially or totally by smectite and mordenite.
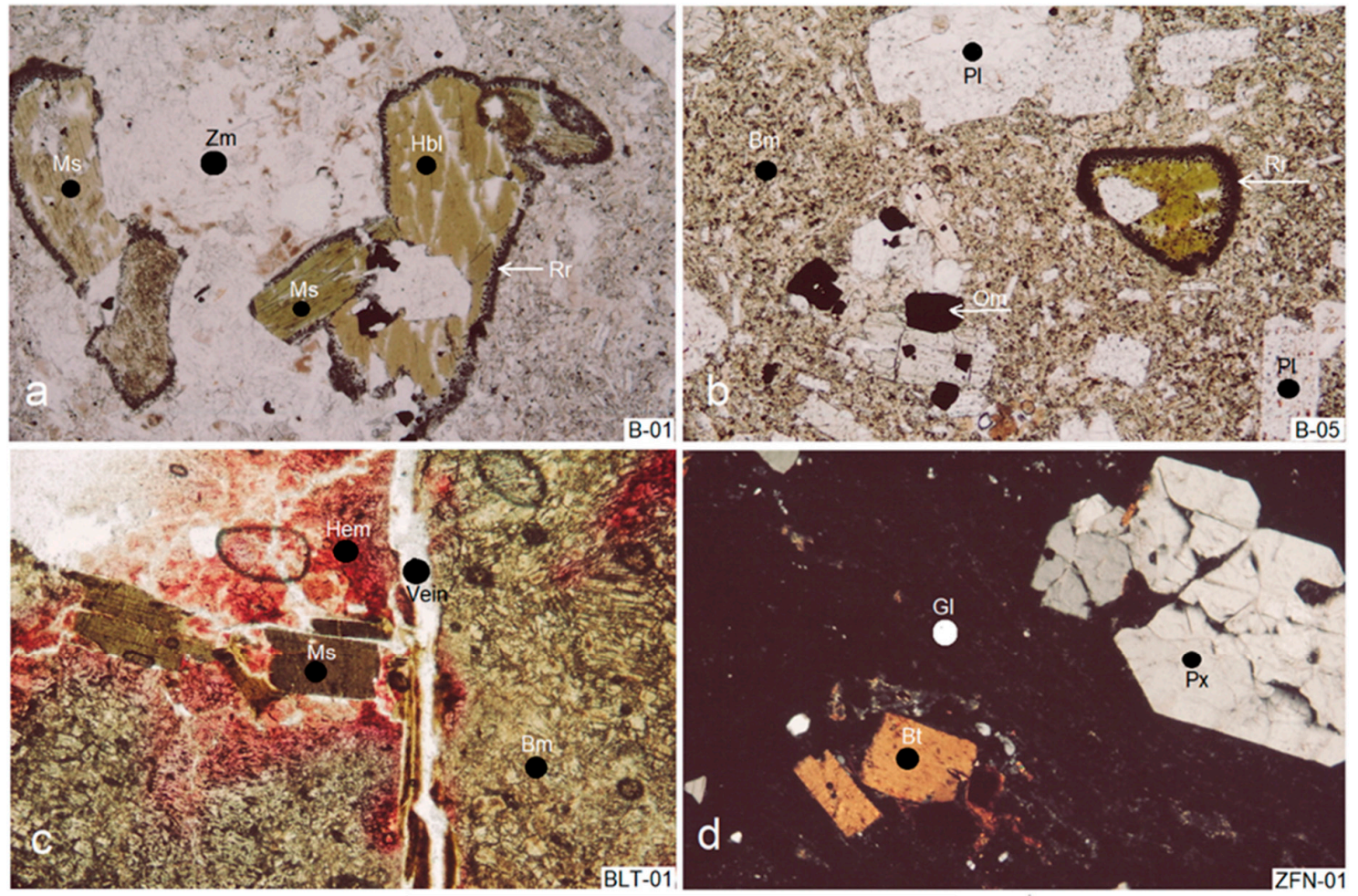

Ms: Muscovite / Hbl: Hornblende / Pl: Plagioclase / Bt: Biotite / Px: Pyroxene / Om: Opaque minerals / Gl: Glass / Bm: Bentonitised matrix / Vein: Carbonated-filled vein $\mathrm{Zm}$ : Matrix altered by zeolitisation processes / Rr: Reation rim between glassy matrix and relict crystals (Hornblende, pyroxene, muscovite, biotite and others)

Figure 5. Petrographic thin section micrograph of bentonite samples from San José-Los Escullos deposit. N// (parallel nicols, $(\mathbf{a}, \mathbf{b}))$ and $\mathrm{Nx}$ (crossed nicols $(\mathbf{c}, \mathbf{d}))$.

The micrograph of the sample BLT-01 (Figure 5c) (Nx) shows a predominance of smectite and muscovite amid transforming into smectite. The hematite is in small fissures and covers the smectite and the mica. Figure $5 \mathrm{~d}(\mathrm{Nx})$ shows fractured pyroxene phenocrystal, completely altered to zeolite, floating on a glass fabric. The biotite crystals show a reaction with the fabric and are partially surrounded by halos of hematite in the paste. There is a biotite crystal in process of matrix alteration (Figure $5 \mathrm{a}, \mathrm{c}, \mathrm{d}$ ). Three types of matrices can be distinguished: in sample B-01, zeolitised; in B-05, combined (zeolitised-bentonised); in BLT-01, bentonised; and in ZFN-01, glassy, with zeolite formation. The comparison among the samples analysed shows that the bentonisation process was more effective in sample 
BLT-01 (Figure 5c), with total development of the clay minerals. In the case of samples B-01, B-05 and ZFN-01, bentonisation did not totally alter the pyroxenes, amphiboles, plagioclase, biotite and muscovite, as these minerals still persist. This fact is observed in Figure 5a-d.

\subsection{X-ray Diffraction}

The phase study showed that the samples analysed have a complex and heterogeneous mineralogy, with the exception of sample BLT-01. The following minerals were detected: montmorillonite-type smectite, illite, vermiculite, halloysite, biotite, muscovite, mordenite, orthoclase, plagioclase, hematite, kaolinite, chlorite, calcite and quartz (Figure 6). According to Figure 6, each sample behaves according to its mineral content. Comparison of X-ray diffraction patterns reveals a clear similarity between samples BLT-01, BFO-01 and B-05, suggesting the presence of similar mineralogical phases. Something very different is observed in samples B-01 to B-03, which shows a greater complexity than the other samples. This is due to the presence of mordenite, plagioclase, muscovite, quartz and kaolinite in greater quantities. The presence of smectite in sample BLT-01 is more evident than in samples BFO-01 and B-05, while in B- 01 to B-03, there is a greater abundance of mordenite.

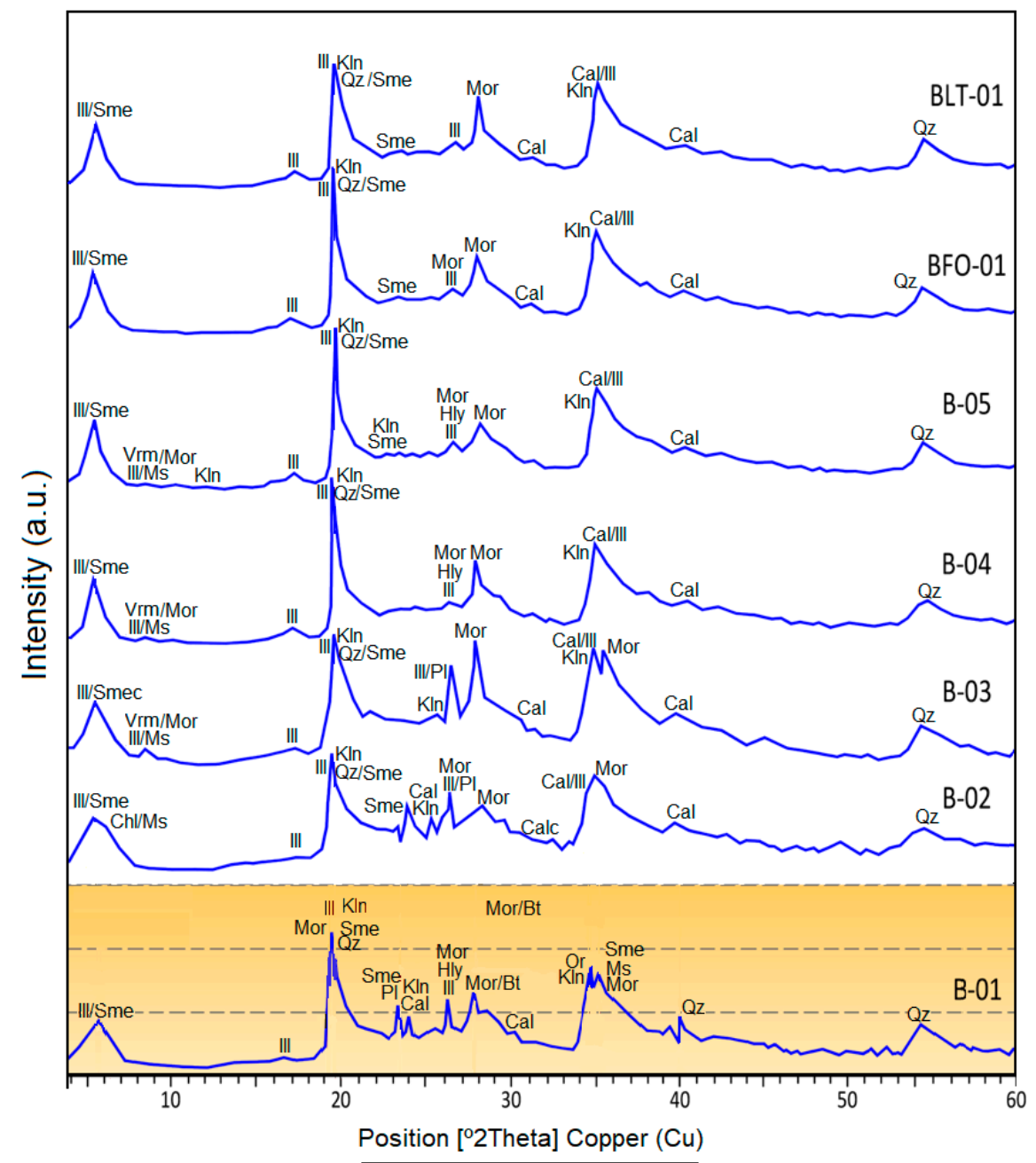

SME: Smectite; Mor: Mordenite; PI: Plagioclase; Bt: Biotite; Or: Orthoclase; Ms: Muscovite; Qz: Quartz KIn: Kaolinite; III: Illite; Chl: Chlorite; Cal: Calcite; Vrm: Vermiculite; Hly: Halloysite BFO-01: sample from the western side of the San José-Los Escullos deposit BLT-01: sample from Los Trancos deposit B-01 to B-05: samples from the research area

Figure 6. X-ray diffraction patterns of bentonite from the research area. 
According to the abovementioned and to the position of the samples in the deposit (Figure 4), it can be deduced that the bentonisation process was less intense towards the centre of the San José-Los Escullos deposit. Samples B-01 to B-03 represent another case of typical zonality in this deposit, as they indicate that the zeolitisation process, unlike bentonisation, decreases from the centre towards the flanks.

The presence of orthoclase, kaolinite and quartz could indicate a previous deposition of acidic volcanic material which was altered to form mordenite and smectites. The presence of hematite suggests that hydrothermal activity took place in this region. This interpretation agrees with Costafreda [24].

The bentonisation and zeolitisation process in the south and southeast of Spain was practically ubiquitous, as has been stated by Martín-Vivaldi [30]; Leone et al. [26]; Linares [31]; Delgado and Reyes [32]; García-Romero et al. [33]; and Martínez et al. [34]. Samples BFO-01 and BLT-01 lie to the west and south of the San José-Los Escullos deposit, respectively. However, the chemical composition (Table 1), as well as the mineralogy, indicate that both bentonisation and zeolitisation processes were caused by large-scale hydrothermal alteration of materials of calc-alkaline composition.

Table 1. Chemical composition of bentonites from the San José-Los Escullos deposit and surrounding areas (\% weight).

\begin{tabular}{|c|c|c|c|c|c|c|c|c|c|c|c|c|}
\hline Sample & $\mathrm{S}_{\mathrm{i}} \mathrm{O}_{2}$ & $\mathrm{Al}_{2} \mathrm{O}_{3}$ & $\mathrm{CaO}$ & $\mathrm{Na}_{2} \mathrm{O}$ & $\mathrm{K}_{2} \mathrm{O}$ & $\mathrm{MgO}$ & $\mathrm{Fe}_{2} \mathrm{O}_{3}$ & $\mathrm{TiO}_{2}$ & LOI * & $\mathrm{Na}_{2} \mathrm{O} / \mathrm{CaO}$ & $\mathrm{MgO} / \mathrm{Al}_{2} \mathrm{O}_{3}$ & $\mathrm{Si} / \mathrm{Al}$ \\
\hline B-01 & 64.30 & 13.71 & 1.03 & 3.3 & 2.3 & 2.5 & 1.3 & 0.123 & 11.5 & 0.58 & 0.18 & 4.1 \\
\hline B-02 & 51.29 & 13.13 & 1.20 & 1.40 & 0.53 & 7.61 & 2.75 & 0.122 & 22.0 & 1.17 & 0.58 & 3.4 \\
\hline B-03 & 52.53 & 13.69 & 1.11 & 0.99 & 0.70 & 7.67 & 2.43 & 0.133 & 20.5 & 0.89 & 0.56 & 3.3 \\
\hline B-04 & 61.3 & 14.76 & 1.24 & 1.56 & 1.92 & 5.0 & 2.46 & 0.116 & 11.5 & 1.26 & 0.34 & 3.6 \\
\hline B-05 & 62.46 & 14.57 & 0.94 & 2.64 & 2.21 & 4.0 & 1.83 & 0.133 & 11.5 & 2.8 & 0.27 & 3.7 \\
\hline BFO-01 & 52.13 & 17.05 & 1.12 & 1.96 & 0.35 & 5.91 & 1.61 & 0.123 & 19.2 & 1.75 & 0.35 & 2.7 \\
\hline BLT-01 & 47.26 & 19.02 & 1.22 & 0.30 & 0.87 & 4.5 & 2.45 & 0.173 & 24.4 & 0.25 & 0.24 & 2.1 \\
\hline ZFN-01 & 67.04 & 12.55 & 1.54 & 2.64 & 1.79 & 1.40 & 1.17 & 0.085 & 11.7 & 1.75 & 0.11 & 4.7 \\
\hline
\end{tabular}

\subsection{Oriented Aggregates}

The analysis of the oriented aggregates attenuated most of the more crystalline phases present in the samples, like mordenite, plagioclase, quartz, orthoclase and others; thus, the following clay minerals were clearly observed in the X-ray diffraction patterns: smectite, vermiculite, illite, kaolinite and halloysite (Figure 7).

Figure 7 represents a case where there is an appreciable amount of mordenite in the sample (ZFN-01), taken at the north of the deposit. Initially the peaks of mordenite of greater intensity masked the clay minerals, whereas, once the sample was treated with ethylene glycol, the vermiculite peaks became visible, as well as illite, kaolinite and halloysite. Another detail worth highlighting is that the main peak of smectite in sample (ZFN-01) is initially in position $2 \theta=6.5$ with interplanar spacing equal to $14 \AA$; once the sample was treated with ethylene glycol it produced a strong peak reflection of the smectite and a displacement from $2 \theta=6.5$ to $2 \theta=5.4$ (Figure 7). In this case, the peak reflection of the smectite has a maximum intensity of $100 \%$ and a maximum spacing of $17 \AA$. This fact proved that the bentonite of the San José-Los Escullos deposit is expansive. 


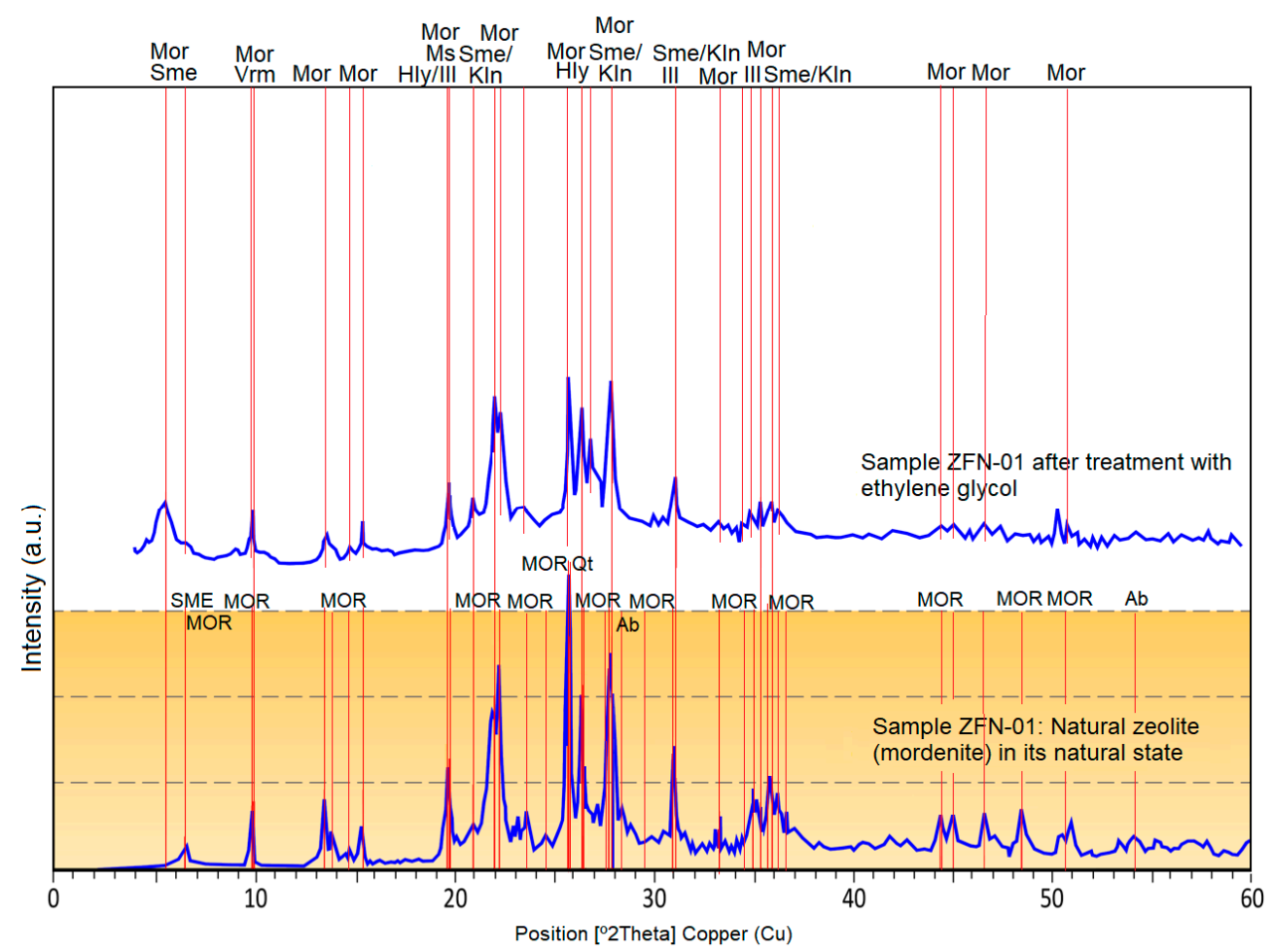

Sme: Smectite; Mor: Mordenite; Qz: Quartz; Vrm: Vermiculite; Hly: Halloysite; III: Illite; Sme-KIn: Smectite-Kaolinite

Figure 7. X-ray diffraction patterns of mordenite accompanied by bentonite clay minerals before and after ethylene glycol treatment.

\subsection{Thermogravimetric Analysis}

The thermal behaviour of the samples analysed shows similarities and differences, according to the variables in the curves (Figure 8). The curve of sample ZFN-01 shows a higher mass loss compared to the other samples. Like Costafreda [24], the authors have linked this fact to the complex composition of the zeolite, due to its $\mathrm{Si} / \mathrm{Al}$ ratio, its capacity for cationic exchange and the proportion of smectite-mordenite. The BLT-01 sample is noted because of its mass loss, which is coherent with the data of LOI represented in Table 1. The BFO-01, B-02 and B-03 show similar behaviour which may be related to its low ratio of $\mathrm{Si} / \mathrm{Al}$, its high values of $\mathrm{LOI}$ and the appreciable content of $\mathrm{MgO}$. The samples B-01 and B-04 behave similarly with regards to their chemical composition, high contents of $\mathrm{SiO}_{2}$ and $\mathrm{Na}_{2} \mathrm{O}$ and the lowest values of LOI.

In addition, it is noted that the TGA curves show a simple decomposition in all samples analysed (Figure 8). In all cases there are three significant inflection points that signal different thermogravimetric processes. These changes occur at intervals of temperature 39.2-86.1 ${ }^{\circ} \mathrm{C}, 86.1-198.1{ }^{\circ} \mathrm{C}$ and $198.1-502.4^{\circ} \mathrm{C}$, which indicate phases of mass loss during heating. Between 39.2 and $86.1^{\circ} \mathrm{C}$ the mass loss is $2.362 \%$, and it indicates a loss of humidity and superficial dehydration in the smectite-mordenite phase. Between 86.1 and $198.1^{\circ} \mathrm{C}$, the mass loss is of $3.972 \%$, which points to the continuation of the process of dehydration, loss of superficial humidity and gasses removal. Between 198.1 and $502.4{ }^{\circ} \mathrm{C}$, the curve shows a loss of mass equivalent to $2.291 \%$ due to the loss of intrareticular water. At $750{ }^{\circ} \mathrm{C}$ the curve stabilises, which could be due to the high $\mathrm{Si} / \mathrm{Al}$ ratio of the mordenite. At this temperature range, the mordenite collapses and the sample structure is reordered. 


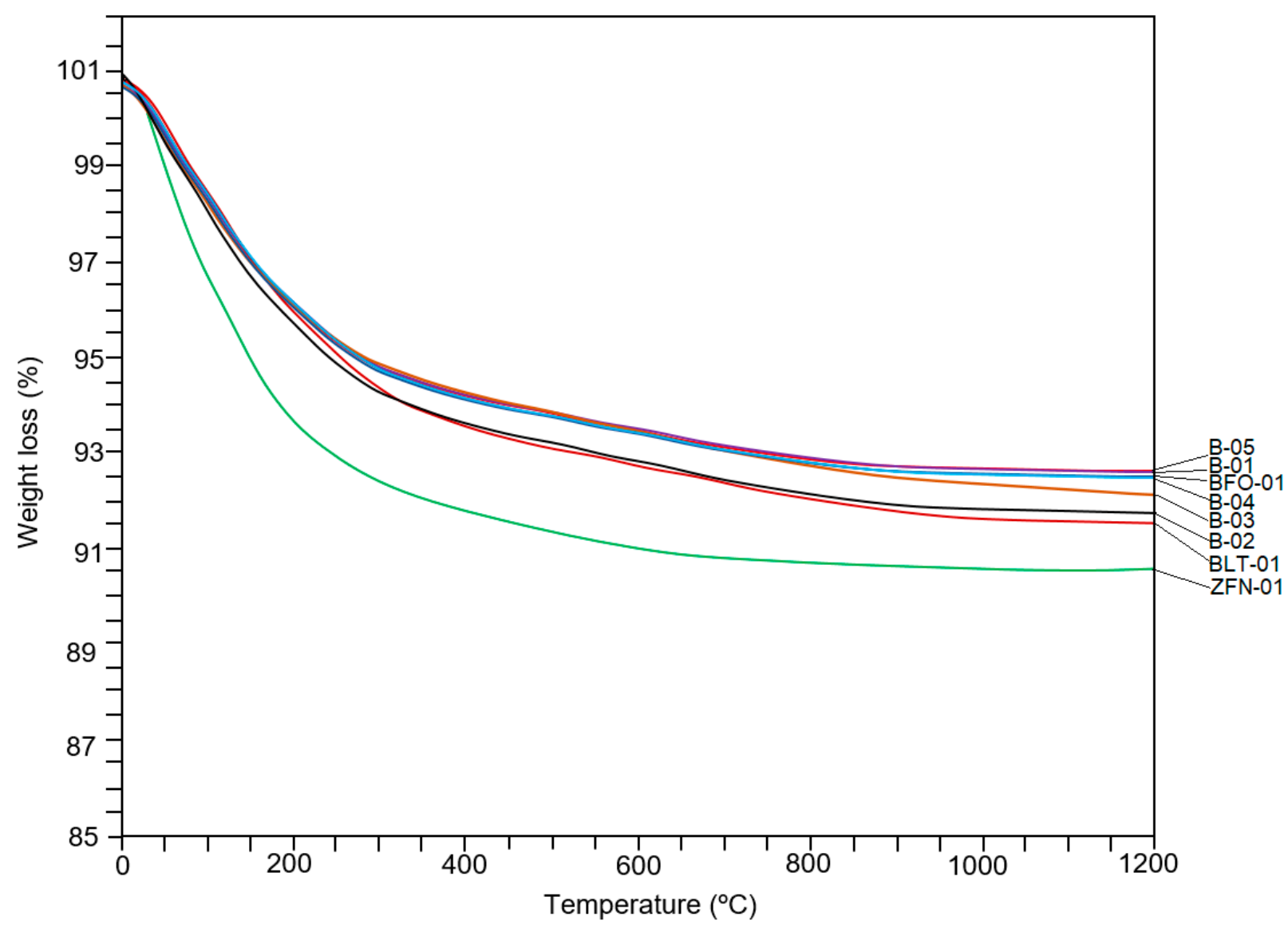

Figure 8. TGA thermograms of bentonites from the research and surrounding areas.

\subsection{X-ray Fluorescence}

The results that stem from the analyses indicate a variable composition in the analysed samples (Table 1). Some bentonites are more siliceous $\left(61.3-64.31 \% \mathrm{SiO}_{2}\right)$ (e.g., B-01, B-04 and B-05) regarding the less siliceous $\left(51.29-52.53 \% \mathrm{SiO}_{2}\right)$ (e.g., B-02, B-03). The high $\mathrm{SiO}_{2}$ contents indicate a marked presence of mordenite in paragenesis with smectite which concurs with what was established by Costafreda [24]; this fact has been proven by comparing the ZFN-01 sample $\left(67.04 \% \mathrm{SiO}_{2}\right)$, from the San José-Los Escullos deposit, with BLT-01 $\left(47.26 \% \mathrm{SiO}_{2}\right)$, from the Los Trancos deposit. García-Romero et al. [33] calculated the $\mathrm{SiO}_{2}(51.25-53.47 \%)$ content in the Los Trancos bentonites, and found it to be slightly higher than the values obtained in this research; however, their calculations are similar for the $\mathrm{Al}_{2} \mathrm{O}_{3}(17.01-17.75 \%)$, the $\mathrm{MgO}(4.56-4.87 \%)$, the $\mathrm{Na}_{2} \mathrm{O}(0.51-1.07 \%)$, the $\mathrm{K}_{2} \mathrm{O}(0.14-0.43 \%)$, the $\mathrm{CaO}(1.05-1.32 \%)$ and the $\mathrm{Fe}_{2} \mathrm{O}_{3}(2.21-2.41 \%)$ (Table 2). The $\mathrm{CaO}$ content in the samples from the San José-Los Escullos deposit is discrete and homogeneous with respect to $\mathrm{Na}_{2} \mathrm{O}$ and $\mathrm{K}_{2} \mathrm{O}$ (Figure 9a), emphasising its alkaline character. This conclusion coincides with what was established by predecessor researchers [32,35-37].

Table 2. Chemical composition (wt\% oxides) of bentonites from the Los Trancos deposit, by GarcíaRomero et al. [33].

\begin{tabular}{lccccccccc}
\hline Sample & $\mathrm{S}_{\mathbf{i}} \mathrm{O}_{2}$ & $\mathrm{Al}_{2} \mathrm{O}_{3}$ & $\mathrm{CaO}$ & $\mathrm{Na}_{\mathbf{2}} \mathrm{O}$ & $\mathrm{K}_{\mathbf{2}} \mathrm{O}$ & $\mathrm{MgO}$ & $\mathrm{Fe}_{\mathbf{2}} \mathrm{O}_{3}$ & $\mathrm{TiO}_{2}$ & $\mathrm{LOI}^{*}$ \\
\hline LTBB & 52.12 & 17.75 & 1.29 & 0.51 & 0.14 & 4.56 & 2.41 & 0.20 & 20.77 \\
\hline LTBV & 51.25 & 17.01 & 1.32 & 0.51 & 0.43 & 4.78 & 2.31 & 0.17 & 20.61 \\
\hline LTBN & 53.47 & 17.21 & 1.05 & 1.07 & 0.27 & 4.87 & 2.21 & 0.16 & 19.42 \\
\hline
\end{tabular}



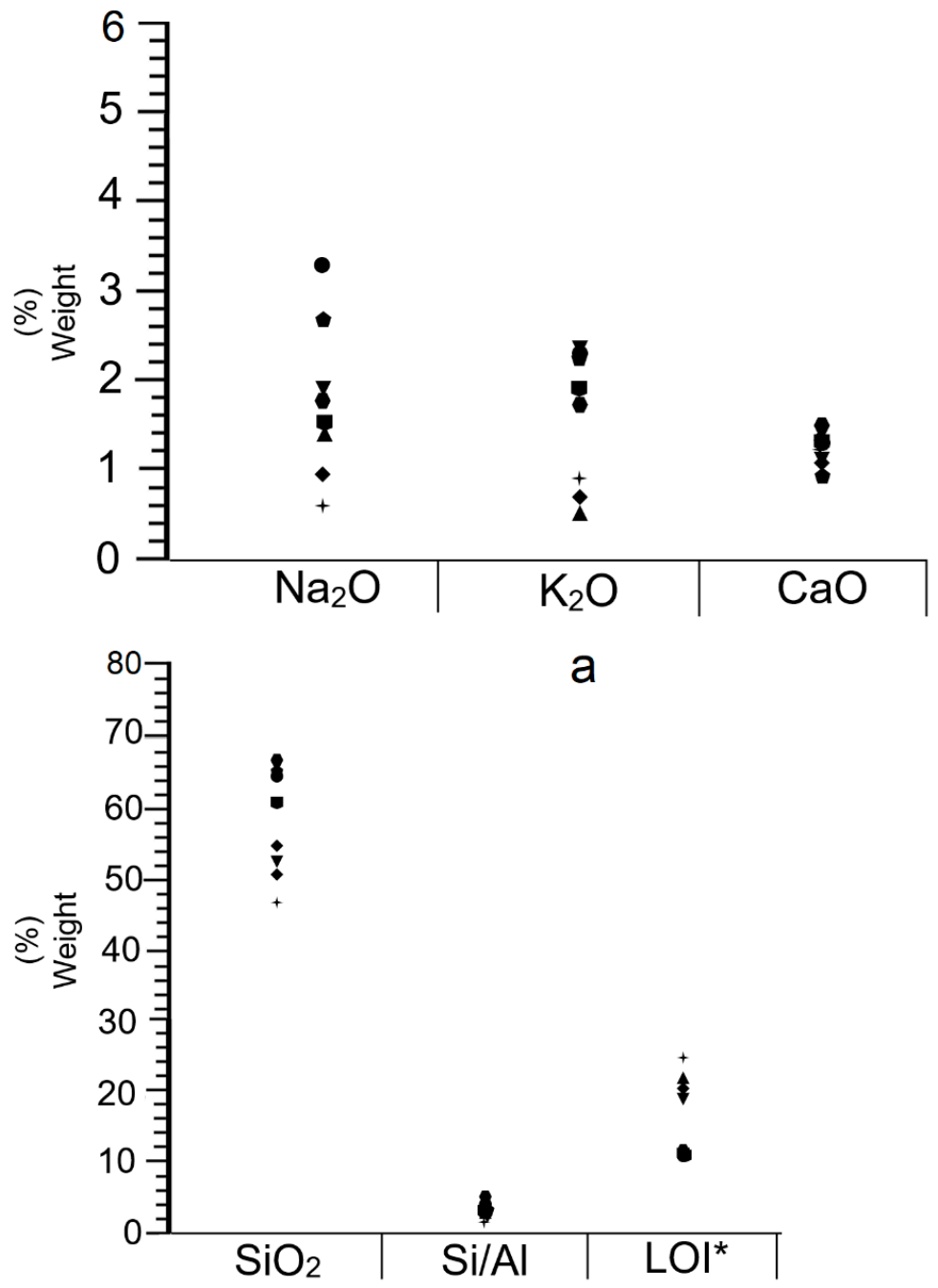

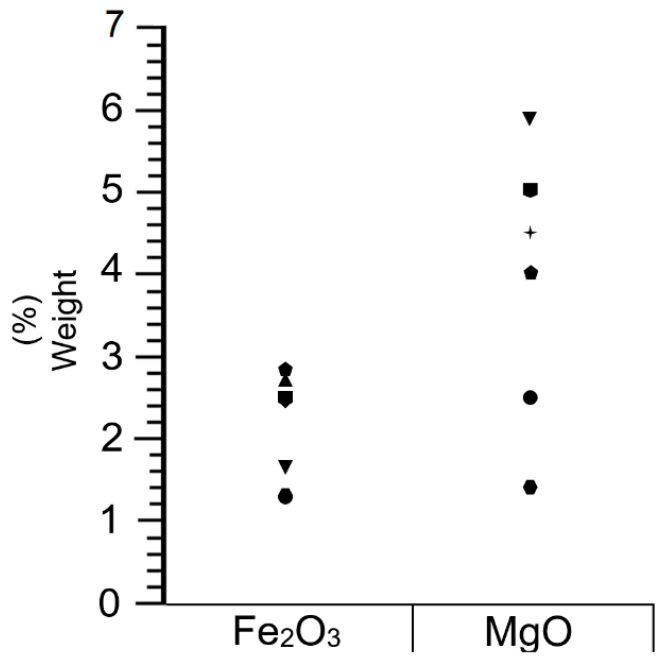

b
- B-01

$\triangle \mathrm{B}-02$

- B-03

- B-04

- B-05

$\checkmark$ BFO-01

+ BLT-01

- ZFN-01

\section{C}

Figure 9. (a-c). Behaviour of alkaline, alkaline earth and other compounds in bentonites from the San José-Los Escullos deposit and surrounding areas. ${ }^{*}$ Loss on ignition.

The hydrothermal processes displaced the iron ions and concentrated them in the bentonites, producing a marked alteration in the bentonites with typical beige and yellow colours of samples B-01 to 05 and BFO-1 (Figure 3), which differentiates them notably from sample BLT-01. The contents of $\mathrm{Fe}_{2} \mathrm{O}_{3}(1.3-2.75 \%)$, as seen in Table 1, focus of this type of variation in the southern and western sides of the San José-Los Escullos deposit. The mobilisation of the iron ions could have been helped by the placement of subvolcanic bodies of dacitic composition in the peripheries of the Los Frailes caldera [24]; this reasoning fits well with the description made by Martinez et al. [34] and Perez del Villar et al. [38] regarding a dome sited in the Cala del Tomate. These researchers applied the name rubefaction to refer to the ferruginous alteration that some bentonites possess in the south of the Iberian Peninsula.

The $\mathrm{MgO}$ contents are even more of an anomaly (4.0-7.67\%) in samples B-01 to B-05 (Table 1 and Figure 9 b), possibly provoked by a combined process of removal-precipitation of the $\mathrm{Mg}^{2+}$ ions from the amphiboles and pyroxene of the dacites and andesites altered by hydrothermal processes.

There is an inverse relationship among $\mathrm{SiO}_{2}$, loss on ignition (LOI) and $\mathrm{Si} / \mathrm{Al}$ ratio in the analysed samples (Figure 9c). It was observed that the bentonites richer in $\mathrm{SiO}_{2}$ have 
lower $\mathrm{LOI}$ values and high $\mathrm{Si} / \mathrm{Al}$ ratios (e.g., B-01, B-04, B-05 and ZFN-01). A different case occurred with the other samples analysed (B-02, B-03, BFO-01, BLT-01) where low $\mathrm{SiO}_{2}$ contents are related to high $\mathrm{LOI}$ values and a low $\mathrm{Si} / \mathrm{Al}$ ratio. The first case characterises bentonites that are not at all expansive or only slightly, while the second case indicates that the bentonites are expansive. All of the above can be summarised as follows: more siliceous bentonites, with higher $\mathrm{Si} / \mathrm{Al}$ ratios, have lower loss on ignition (LOI) caused by excess silica (Figure 9c); however, when the $\mathrm{Si} / \mathrm{Al}$ ratio is low, the samples have a high loss on ignition. Therefore, an inverse ratio was observed, as shown in Figure 9c.

\subsection{Scanning Electron Microscopy}

Bentonite sample analysis by way of scanning electron microscopy outlined the presence of various types of minerals. These were: smectite, mordenite, halloysite and pyroxene (Figure 10a-d).

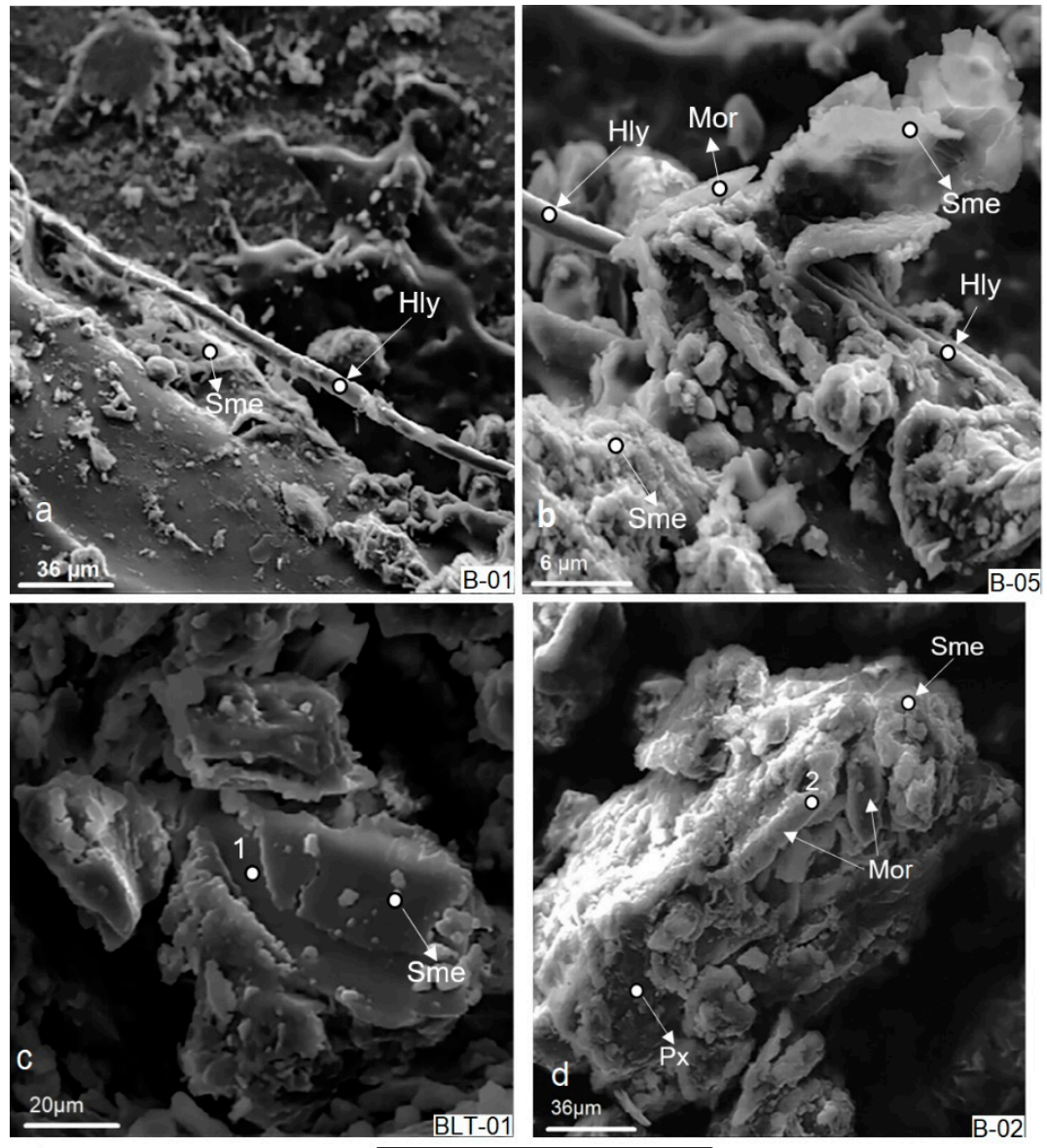

Sme: Smectite; Mor: Mordenite; Hly: Halloysite; Px: Pyroxene

Figure 10. Scanning electron microscopy (SEM) micrographs of the bentonite samples (a-d).

Smectite in its montmorillonite variety is the most common mineral, as observed in Figure 10a-d. A comparison between the different samples analysed allowed to establish different morphological properties of the mineral phases. For example, in sample B-01 smectite forms small irregular white to light grey masses (Figure 10a). In sample B-05 it forms light grey and white and can be translucent with compact efflorescence (Figure 10b). In sample BLT-01 it appears to form large compact and irregular masses (Figure 10c), and is practically monomineral, which indicates a high purity. In sample B-02 (Figure 10d) it forms compact aggregates together with mordenite. Both smectite and mordenite developed at the expense of relict minerals such as pyroxene and plagioclase, as well as volcanic glass. 
The mordenite found in samples B-05 and B-02 forms elongated crystals $>36 \mu \mathrm{m}$ in size, as well as compact crystalline aggregates (Figure 10b,d). Mordenite is syngenetic with smectite. In Figure $10 \mathrm{~d}$ both mordenite and smectite grow at the expense of an altered pyroxene crystal.

\subsection{Pozzolanicity Test}

According to Figure 11a, all the samples analysed have pozzolanic behaviour at 8 days of testing, as their position is below the solubility isotherm $\left(40^{\circ} \mathrm{C}\right)$, as indicated by UNE-EN 196-5:2011 [29]. Specifically, the zeolite sample (ZFN-01) is the most reactive, followed by B-01 and B-05. The other samples, according to their reactivity with $\mathrm{Ca}(\mathrm{OH})_{2}$, are in the following order: B-04, BFO-01, B-02, B-03 and BLT-01. These data reflect the capacity of the samples to trap the free lime in the solution and the formation of stable reaction products, such as portlandite and tobermorite. The pozzolanic activity is reflected in the decrease of $\mathrm{Ca}(\mathrm{OH})_{2}$ concentration values from $7.9 \mathrm{mmol} / \mathrm{L}$ to $4.1 \mathrm{mmol} / \mathrm{L}$, where sample ZFN-01 is the most pozzolanic. Taking this into account, it should be noted that the bentonite samples contribute effectively to the reaction process. The concentration of the bentonite samples under the curve indicates that B-02, B-03, B-04 and BFO-01 behave similarly, which differentiates them from BLT-01, B-01 and B-05. On the other hand, B-01 and B-05 show behaviour that is quite similar.
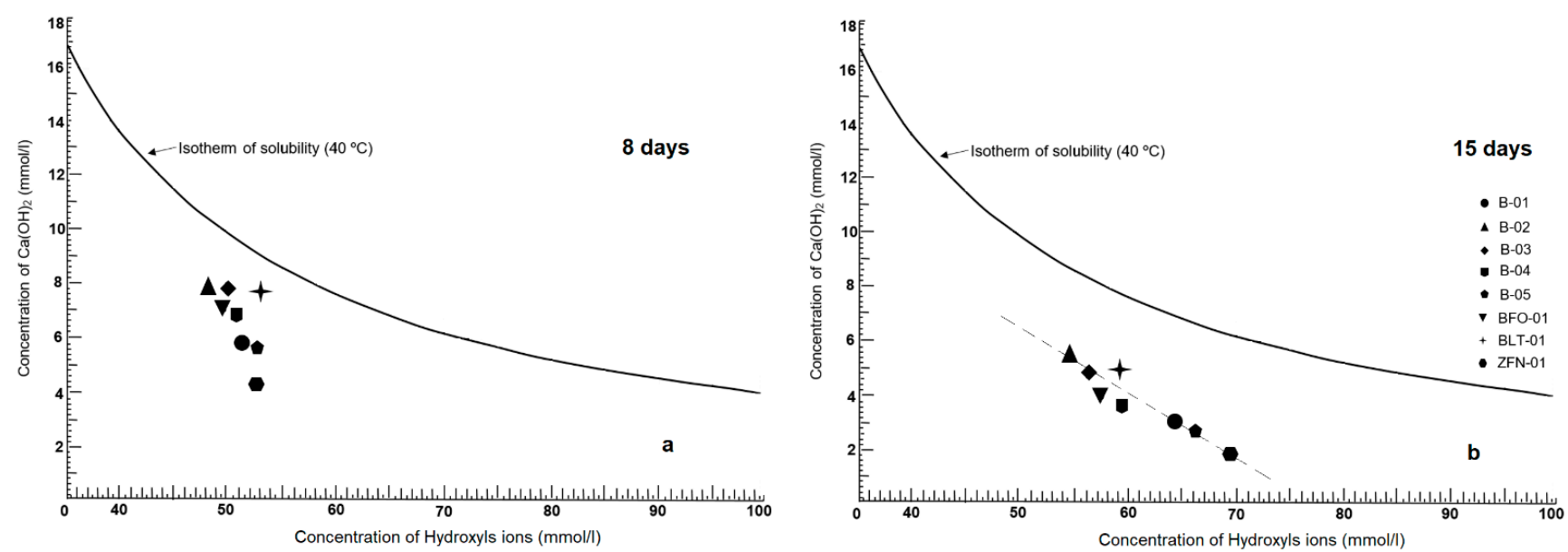

Figure 11. Graphs of $\mathrm{Ca}(\mathrm{OH})_{2}$ concentration vs. hydroxyl ions (mmol/L) showing the pozzolanic reactivity at 8 and 15 days $(\mathbf{a}, \mathbf{b})$.

According to the data provided in Table 1, B-01 and B-05 are the samples with the highest $\mathrm{SiO}_{2}$ and $\mathrm{Al}_{2} \mathrm{O}_{3}$ contents, which is an indispensable condition for a sample to be considered a pozzolan [24]; this is because both $\mathrm{SiO}_{2}$ and $\mathrm{Al}_{2} \mathrm{O}_{3}$ represent the acid phase that causes the pozzolanic reaction in a very alkaline solution [29]. Additionally, the high $\mathrm{Na}_{2} \mathrm{O}$ and $\mathrm{K}_{2} \mathrm{O}$ contents of these samples also confirm the outstanding pozzolanic properties of both samples. Because of this fact, it shows why ZFN-01 is the most pozzolanic reference sample, from which the hierarchy of the quality of each sample studied has been traced.

In addition, it can be deduced that the bentonites from the San José-Los Escullos deposit show a more efficient pozzolanic behaviour than the sample from the Los Trancos deposit (BLT-01) in the 8 days of testing (Figure 11a).

According to the graph in Figure 11b, for 15 days, the pozzolanic reaction of all samples visibly increased. Sample ZFN-01 is still more pozzolanic, followed by B-05, B-01, B-04, BFO-01, B-03, BLT-01 and B-02. The pozzolanic behaviour of BLT-01 stands out in relation to B-02 and B-03 from 8 to 15 days of testing. The set of samples analysed has caused a decrease in $\mathrm{Ca}(\mathrm{OH})_{2}$ concentration from $4.25 \mathrm{mmol} / \mathrm{L}$ to $<2 \mathrm{mmol} / \mathrm{L}$ at 15 days of analysis. 
Another important aspect to highlight in Figure $11 \mathrm{~b}$ is the linear trend in the behaviour of the samples analysed, which is different from that observed in Figure 11a. This is interpreted as a consequence of the complex mineralogical, petrological and chemical constitution of the samples discussed in Section 4.1 to Section 4.6, which causes different behaviours in the first stages of reaction with $\mathrm{Ca}(\mathrm{OH})_{2}$. One of the consequences of this is the slow initial reactivity. However, the reactivity becomes stronger with time (15 days), when all components of the samples start to react with $\mathrm{Ca}(\mathrm{OH})_{2}$ (Figure 11b). This aspect is important as these are the same mechanisms that provide mechanical strength to cements, mortars and concretes [24].

The remarkable inclination of the trend line towards the abscissa axis (Figure 11b) is highly relevant in this investigation, because it permits the prediction of an uninterrupted development of the pozzolanic reaction over time. This is interpreted as a decisive factor to use the researched bentonites as pozzolans.

The presence of zeolite in almost all bentonite samples, according to the XRD and SEM tests (Figures 6, 7 and 10), is a very important factor contributing to the reinforcement of pozzolanic properties; this is due to several intrinsic factors: porosity, cation exchange capacity, high active surface area and high adsorption capacity.

According to the thermograms in Figure 8, the bentonites studied lose water and cations with increasing temperature, which activates their ion-exchange capacities and their pozzolanic reactivity.

\section{Conclusions}

The bentonites from the San José-Los Escullos deposit have pozzolanic behaviour. The complex mineralogical, petrological and chemical constitution reinforces its pozzolanic capacity. These bentonites are able to react with $\mathrm{Ca}(\mathrm{OH})_{2}$ for a long time, which allows the effective neutralisation of free lime in the reaction system and the formation of secondary reaction products, such as tobermorite, which prevents further reaction with sulphates and chlorides. The use of these bentonites as pozzolans could have several advantages, for example, sustainable manufacture of pozzolanic cements, mortars and concretes with high durability and no negative impact on the environment. On the other hand, the specific use of these bentonites in the manufacture of clinker could prevent the emission of $\mathrm{CO}_{2}$ into the atmosphere, thus avoiding the greenhouse effect. Furthermore, concretes and mortars manufactured with bentonite could prevent the degradation of structures built in coastal environments and control the formation of pollutant flows. Bentonite has good pozzolanic capacity compared to zeolite. It is therefore concluded that bentonite and zeolite from the San José-Los Escullos deposit could be mined together, which would increase the productivity and sustainability of the mining activity.

Author Contributions: Conceptualisation, J.L.C. and D.A.M.; methodology, J.L.C. and D.A.M.; software, J.L.C. and D.A.M.; validation, J.L.C. and D.A.M.; formal analysis, J.L.C. and D.A.M.; investigation, J.L.C. and D.A.M.; resources, J.L.C. and D.A.M.; data curation, J.L.C. and D.A.M.; writing-original draft preparation, J.L.C. and D.A.M.; writing-review and editing, J.L.C. and D.A.M.; visualisation, J.L.C. and D.A.M.; supervision, J.L.C. and D.A.M.; project administration, J.L.C. and D.A.M.; funding acquisition, J.L.C. and D.A.M. All authors have read and agreed to the published version of the manuscript.

Funding: This work has been partially funded for the Universidad Politécnica de Madrid, through the Projects AL15-PDI-32 and AL16-PDI-11.

Institutional Review Board Statement: Not applicable.

Informed Consent Statement: Not applicable.

Data Availability Statement: Data is contained within the article. 
Acknowledgments: The authors wish to thank Laboratorio LOEMCO for preparing the samples and conducting chemical pozzolanicity and petrographic tests. J.L.C. and D.A.M. would like to thank the centralised laboratory of the Escuela Técnica Superior de Ingenieros de Minas y Energía (Universidad Politécnica de Madrid) for the OA analysis. The authors would like to thank A.L.S., of the Department of Geological and Mining Engineering, for processing the images. J.L.C. thanks the Universidad Federal de Pernambuco (Brazil) for thermic analysis (TGA).

Conflicts of Interest: The authors declare that they have no known competing financial interests or personal relationships that could have appeared to influence the work reported in this paper.

\section{References}

1. Cara, S.; Carcangiu, G.; Padalino, G.; Palomba, M.; Tamanini, M. The bentonites in pelotherapy: Thermal properties of clay pastes from Sardinia, Italy. Appl. Clay Sci. 2000, 16, 125-132. [CrossRef]

2. Bergaya, F.; Lagaly, G. General introduction: Clays, clay minerals, and clay science. In Handbook of Clay Science. Developments in Clay Science; Elsevier: Amsterdam, The Netherlands, 2006; Volume 1, pp. 1-18. [CrossRef]

3. Buchwald, A.; Hohmann, M.; Posern, K.; Brendler, E. The suitability of thermally activated illite/smectite clay as raw material for geopolymer binders. Appl. Clay Sci. 2009, 46, 300-304. [CrossRef]

4. Habert, G.; Choupay, N.; Escadeillas, G.; Guillaume, D.; Montel, J.M. Clay content of argillites: Influence on cement-based mortars. Appl. Clay Sci. 2009, 43, 322-330. [CrossRef]

5. Kaci, A.; Chaouche, M.; Andréani, P.-A. Influence of bentonite clay on the rheological behaviour of fresh mortars. Cem. Concr. Res. 2011, 41, 373-379. [CrossRef]

6. Bertagnolli, C.; Kleinübing, S.J.; Carlos da Silva, G.M. Preparation and characterization of a Brazilian bentonite clay for removal of copper in porous beds. Appl. Clay Sci. 2011, 53, 73-79. [CrossRef]

7. Slamova, R.; Trckova, M.; Vondruskova, H.; Zraly, Z.; Pavlik, I. Clay minerals in animal nutrition. Appl. Clay Sci. 2011, 51, 395-398. [CrossRef]

8. Pelayo, M. Estudio del Yacimiento de Bentonita de Morrón de Mateo (Cabo de Gata, Almería) como Análogo Natural del Comportamiento de la Barrera de Arcilla de un Almacenamiento de Residuos Radiactivos. Ph.D. Thesis, Universidad Complutense de Madrid, Madrid, Spain, 2013; 311p.

9. Hassan, A.Z.A.; Abdel, W.M.M. The combined effect of bentonite and natural zeolite on sandy soil properties and productivity of some crops. Topclass J. Agric. Res. 2013, 1, 22-28.

10. Zhou, C.H.; Zhao, L.Z.; Wang, A.Q.; Chen, T.H.; He, H.P. Current fundamental and applied research into clay minerals in China. Appl. Clay Sci. 2016, 119, 3-7. [CrossRef]

11. Park, J.H.; Shin, H.J.; Kim, M.H.; Kim, J.S.; Kang, N.; Lee, J.Y.; Kim, K.T.; Lee, J.I.; Kim, D.D. Application of montmorillonite in bentonite as a pharmaceutical excipient in drug delivery systems. J. Pharm. Investig. 2016, 46, 363-375. [CrossRef] [PubMed]

12. Pandey, S.; Ramontja, J. Natural bentonite clay and its composites for Dye removal: Current state and future potential. Am. J. Chem. Appl. 2016, 3, 8-19.

13. Luqman, A.; Enobong, R. Bioactivity of quaternary glass prepared from bentonite clay. J. Adv. Ceram. 2016, 5, 47-53. [CrossRef]

14. Aravindhraj, M.; Sapna, B.T. Influence of Bentonite in Strength and Durability of High Performance Concrete. Int. Res. J. Eng. Technol. 2016, 3, 5 .

15. Masindi, V. Application of cryptocrystalline magnesite-bentonite Clay hybrid for defluoridation of underground water resources: Implication for point of use treatment. J. Water Reuse Desalination 2017, 7, 3. [CrossRef]

16. Kim, M.J.; Lee, S.R.; Yoon, S.; Jeon, J.S.; Kim, M.S. Optimal initial condition of a bentonite buffer with regard to thermal behavior in a high-level radioactive waste repository. Comput. Geotech. 2018, 104, 109-117. [CrossRef]

17. Masood, B.; Elahi, A.; Barbhuiya, S.; Ali, B. Mechanical and durability performance of recycled aggregate concrete incorporating low calcium bentonite. Constr. Build. Mater. 2020, 237, 117760. [CrossRef]

18. Wu, H.L.; Jin, F.; Zhou, A.; Du, Y.J. The engineering properties and reaction mechanism of MgO-activated slag cement-clayey sand-bentonite (MSB) cut-off wall backfills. Constr. Build. Mater. 2021, 271, 121890. [CrossRef]

19. Wang, Y.; Zhang, H.; Tan, Y.; Zhu, J. Sealing performance of compacted block joints backfilled with bentonite paste or a particle-powder mixture. Soils Found. 2021, 61, 496-505. [CrossRef]

20. Cunningham, C.; Arribas, A., Jr.; Rytuba, J.; Arribas, A. Mineralized and unmineralized calderas in Spain. Part I: Evolution of the Los Frailes Caldera. Mineral. Depos. 1990, 25, 21-28. [CrossRef]

21. Arribas, A. Las Mineralizaciones de Metales Preciosos de la Zona Central del Cabo de Gata (Almería) en el Contexto Metalogénico del Sureste de España. Ph.D. Thesis, Universidad de Salamanca, Salamanca, Spain, 1992; pp. 109-148, $186-237$.

22. Rytuba, J.; Arribas, A., Jr.; Cunningham, C.; McKee, E.; Podwysocki, M.; Smith, J.; Kelly, W.; Arribas, A. Mineralized and unmineralized calderas in Spain; Part II. Evolution of the Rodalquilar caldera complex and associates gold-alunite deposits. Mineral. Deposita 1990, 25, 529-535. [CrossRef]

23. Fernández-Soler, J.M. El Volcanismo Calco-Alcalino de Cabo de Gata (Almería). Ph.D. Thesis, Universidad de Granada, Granada, Spain, 1992; 243p. 
24. Costafreda, J.L. Geología, Caracterización y Aplicaciones de las Rocas Zeolíticas del Complejo Volcánico de Cabo de Gata (Almería). Ph.D. Thesis, Universidad Politécnica de Madrid, Madrid, Spain, 2008; 515p.

25. Reyes, E. Mineralogía y Geoquímica de las Bentonitas de la Zona Norte de Cabo de Gata (Almería). Ph.D. Thesis, Universidad de Granada, Granada, Spain, 1977; 650p.

26. Leone, G.; Reyes, E.; Cortecci, G.; Pochini, A.; Linares, J. Genesis of bentonitas from Cabo de Gata, Almería, Spain: A stable isotope study. Clay Miner. 1983, 18, 227-238. [CrossRef]

27. Pelayo, M.; García-Romero, E.; Labajo, M.A.; Pérez del Villar, L. Occurrence of Fe-Mg-rich smectites and corrensite in the Morrón de Mateo bentonite deposit (Cabo de Gata region, Spain): A natural analogue of the bentonite barrier in a radwaste repository. Appl. Geochem. 2011, 26, 1153-1168. [CrossRef]

28. Google Earth. Available online: https://earth.google.com/web/@36.78396874,-2.07282152,311.26637664a,8201.3672037d,35y,0h, 0t,0r (accessed on 17 May 2021).

29. British Standard Institution. UNE-EN 196-5:2011. Methods of Testing Cement-Part 5: Pozzolanicity Test for Pozzolanic Cement; British Standard Institution: London, UK, 2011.

30. Martín-Vivaldi, J.L. The Bentonites of Cabo de Gata (Southeast Spain) and of Guelaya Volcanic Province (North Morocco). Clays Clay Miner. 1962, 11, 327-357. [CrossRef]

31. Linares, J. Chemical evolutions related to the genesis of hydrothermal smectites, Almería, SE Spain. In Geochemistry and Mineral Formation in the Earth Surface; Rodríguez-Clemente, R., Tardy, Y., Eds.; CSIC-CNRS: Madrid, Spain, 1987; pp. 567-584.

32. Delgado, A.; Reyes, E. Isotopic study of the diagenetic and hydrothermal origins of the bentonite deposits at Los Escullos (Almería, Spain). In Current Research in Geology Applied to Ore Deposits; Fenoll, P., Torres-Ruiz, J., Gervilla, F., Eds.; Universidad de Granada: Granada, Spain, 1993; pp. 657-678.

33. García-Romero, E.; Manchado, E.M.; Suárez, M.; García-Rivas, J. Spanish Bentonites: A review and new data on their geology, mineralogy, and crystal chemistry. Minerals 2019, 9, 696. [CrossRef]

34. Martínez, J.A.; Caballero, E.; Jiménez, C.; Linares, J. The effect of a volcanic dome over the Cala del Tomate bentonite (Almería). Cadernos Lab. Xeolóxico Laxe 2000, 25, 67-69.

35. Caballero, E. Quimismo del Proceso de Bentonitización en la Región Volcánica de Cabo de Gata (Almería). Ph.D. Thesis, Universidad de Granada, Granada, Spain, 1985; 328p.

36. Benito, R.; García-Guinea, J.; Valle-Fuentes, F.J.; Recio, P. Mineralogy, geochemistry and uses of mordenite-bentonite ash-tuff beds of Los Escullos, Almería, Spain. J. Geochem. Explor. 1998, 62, 229-240. [CrossRef]

37. Huertas, F.J.; Carretero, P.; Delgado, J.; Linares, J.; Samper, J. An experimental study on the ion-exchange behaviour of the smectite of Cabo de Gata (Almería, Spain): FEBEX Bentonite. J. Colloid Interface Sci. 2001, 239, 409-416. [CrossRef] [PubMed]

38. Pérez del Villar, L.; Delgado, A.; Pelayo, M.; Fernández Soler, J.M.; Tsige, A.M.; Cózar, J.S.; Reyes, A. Natural Thermal Effects Induced on the Bentonite from de Cala del Tomate Deposit (Cabo de Gata, Almería); BARRA II Project, Termal Effect; CIEMAT/DIAE/54450/1/04 Report No. 82; Internal Report of CIEMAT: Madrid, Spain, 2004. 